\title{
SUÇA SÜRÜKLENEN ÇOCUKLARIN DEĞERLENDİRİLMESİNDE EKOLOJİK SISTEM YAKLAŞIMININ KULLANIMI: OLGU SUNUMU
}

\author{
Osman ZORBAZ1 , Filiz BİLGE²
}

\section{Öz}

$\mathrm{Bu}$ çalışmanın amacı, suça sürüklenen çocukların psikososyal değerlendirmesinde ekolojik sistem yaklaşımının kullanılmasını bir olgu çerçevesinde incelemektir. Olgu; 16 yaşında, Ankara Çocuk Mahkemesine Subat 2015 ayında "taksirle bir kişinin yaralanmasına neden olma” suçundan hakkında ceza davası açılan ve çalışmaya katılmayı kabul eden M'dir. M’ye öncelikle çalışma hakkında bilgi verilmiş ve hazırlanan yarı yapılandırılmış görüşme formu çerçevesinde görüşmeler yapılmıştır. Çalışmada olgunun psikososyal durumu ekolojik sistem yaklaşımı katmanlarına göre koruyucu ve risk faktörleri olarak açıklanmıștır. Çalıșma sonucunda ekolojik sistem yaklaşımının suça sürüklenen çocukların değerlendirilmesinde etkili biçimde kullanılabileceği düşünülmektedir.

Anahtar Kelimeler: Ergenlik, suça sürüklenen çocuk, çocuk suçluluğu, ekolojik sistem yaklaşımı, önleme

\footnotetext{
${ }^{1}$ Dr. Osman Zorbaz, T.C. Adalet Bakanlığı, Giresun Aile Mahkemesi, e-posta: osmanzorbaz07@gmail. com, Orcid No: 0000-0002-1744-4711

${ }^{2}$ Prof. Dr. Filiz Bilge, Hacettepe Üniversitesi, Eğitim Fakültesi, Eğitim Bilimleri Bölümü, e-posta: fbilge@ hacettepe.edu.tr, Orcid No: 0000-0001-7502-3846
} 


\title{
THE USE OF THE ECOLOGICAL SYSTEM APPROACH IN ASSESMENT OF JUVENILE DELINQUENCY: A CASE STUDY
}

\begin{abstract}
The aim of the present study is to examine the use of an ecological system approach in psychosocial to assessment children who are involved in crime via case study. Case $M$; he was convicted in Ankara Juvenile Court February 2015 at the age of 16 for 'causing a personal injury and agreed to participate in the study. M. was informed about the study and interviews were conducted within the framework of the semi-structured interview form. In this study, the psychosocial status of the case was explained as protective and risk factors according to the ecological system approach layers. As a result of the study, it is evaluated that the ecological system approach can be used effectively in assessments to children who are dragged to crime.
\end{abstract}

Key Words: Adolescence, child dragged to crime, juvenile delinquency, ecological system approach, prevention 


\section{Giriș}

Çocukların korunması ve haklarının gözetilmesi tüm dünyada en önemli problem alanlarından biridir. Suça yönelen, suç işleme ve suç mağduru olma riski taşıyan çocuklara ilişkin tartışmalar gerek gelişmiş, gerekse gelişmekte olan ülkelerin ana gündeminde hala önemli bir yer tutmaktadır. Gülşen İçliye (2009) göre suça sürüklenme olgusu; ekonomik, sosyal, kültürel ve politik birçok faktörle ilişkilidir. Güler, Sungur ve Kütük’e (2018) bu faktörleri düşük sosyal destek, yoksulluk, ebeveynlerin ve/veya çocuğun alkol ve madde kullanımı, tek ebeveynli veya geniş ailede büyümek, ebeveyn denetiminin olmaması olarak sıralamaktadırlar. Bu faktörler tüm ülkelerdeki suça sürüklenen çocuklarda benzerlik göstermektedir. Başka bir deyişle, gelişmişlik düzeyi ile birlikte soruna çözüm olanakları ülkeler arasında farklılıklar gösterse de, çocukları bu soruna sürükleyen sosyal koşullar aynı özellikleri taşımaktadır.

Bireysel ve ailesel nedenler ile birlikte artan yoksulluk, göçlerin yol açtığ uyum sorunları, etkisiz sosyal politikalar, yetersiz eğitim gibi sebeplerden dolayı her geçen gün daha fazla sayıda çocuk suça sürüklenebilmektedir (Haştemoğlu, 2012). Türkiye İstatistik Kurumu’nun (2018) verilerine göre Türkiye genelinde 12-18 yaş aralığında güvenlik birimlerine (emniyet) suça sürüklenme ile gelen veya getirilen çocuk sayısı 2015 yılında 118.245 iken, 2016 yllında 108.675, 2017 yılında ise 107.984'e düşmüştür. Çocukların suça sürüklenme oranlarında son yıllarda azalma gözlemlense de halen yüksek düzeyde olduğu değerlendirilmektedir.

\section{Çocuk Adalet Sisteminde Suça Sürüklenen Çocuklara Yapılan Psikososyal Müdahaleler}

Suça sürüklenen çocukların sosyal hayata uyumunun artırılması süreci, sağlıklı gelişimlerinin desteklenmesi açısından son derece önemlidir. Birçok ülkede çocuk suçluluğunun önlenmesine yönelik farklı yöntemler kullanmaktadır. Türkiye’de çocuk adalet sisteminin temel kaynağı olan Çocuk Koruma Kanununun yürütülmesi görevi Adalet Bakanlığına verilmiştir. Bu çerçevede çocuk adalet sisteminin koordinasyon görevinin yürütülmesini sağlayacak olan en merkezi paydaşının; çocukların korunması, esenliklerinin gözetilmesi ve yargılanması gibi konularda yetkili karar verme organı olan Çocuk Mahkemeleri olduğu söylenebilir. 
Çocuk Koruma Kanunu (ÇKK), çocuk mahkemelerinde sosyal çalışma görevlisi görevlendirilmesini öngörmektedir. Sosyal çalışma görevlisi; psikolojik danışma ve rehberlik, psikoloji ve sosyal hizmet bölümü mezunu olan meslek mensuplarını ifade eder (ÇKK Madde 3). Bu meslek grupları farklı alan ve eğitim süreçlerinden geçmesine rağmen bireye yardım meslekleri olmaları nedeniyle çocuk mahkemelerinde aynı görevi yürütmektedirler. Çocuk mahkemelerinde sosyal çalışma görevlisi suça sürüklenen veya bir suçun mağduru olan çocuk ile korunma ihtiyacı olan çocuğun yargılama sürecinden olumuz etkilenmemesini sağlamaya çalışır. Bunun yanı sıra çocuğu suça iten faktörlerin araştırılmasında ve altta yatan sorunların çözümünde etkin rol oynar. Sosyal çalışma görevlileri bu işlevleri gerçekleştirirken suça sürüklenen çocuğun yanında onun sosyal çevresiyle de ilişki kurar.

Çocuk Koruma Kanunu çerçevesinde çocuk mahkemelerinde sosyal çalışma görevlilerinin temel görevlerinden birisi, suça sürüklenen çocukla ilgili olarak sosyal inceleme raporu (SİR) hazırlamaktır. Sosyal inceleme, en basit tanımıyla suça sürüklenen çocuğun veya korunma ihtiyacı olan çocuğun kendisinin ve içinde yaşadığı sosyal çevrenin bir uzman tarafından incelenmesi, böylelikle suça sürüklenmenin veya mağduriyetin nedenlerinin daha sağlıklı saptanabilmesinin yanı sıra çocuğun gelişimsel ve psikososyal ihtiyaçlarının karşılanmasına yönelik bir araştırma ve raporlaştırma sürecidir. Sosyal inceleme süreci, suça sürüklenen çocuk ile uzman arasındaki ilişkiye dayanır. Bu ilişki etkin dinlemeye, empatiye ve güvene dayalıdır. Ayrıca bu ilişki çerçevesinde sosyal çalışma görevlisinin suça sürüklenen çocuğun ailesi ve sosyal çevresiyle de ilişki kurması beklenir. Sosyal inceleme raporu ile birlikte suça sürüklenen çocuğun gelişimsel ve psikososyal ihtiyaçları değerlendirilir ve bu doğrultuda bir müdahale planı hazırlanarak çocuk hâkimine sunulur. Sosyal inceleme raporu (SİR) ile mahkemeye, suça sürüklenen çocukların bireysel özellikleri, gelişim dönemi ve içinde bulunduğu psikososyal durum hakkında bilgi sunularak çocuk hakkında verilecek hükmün çocuğun yararına daha uygun olması sağlanır.

Sosyal inceleme raporlarının çocuk adalet sisteminin amaçları ve çocuğun yüksek yararı açısından önemi büyüktür. Raporda yer alan müdahale planı ve öneriler doğrultusunda çocuk hâkimi danışmanlık, eğitim, bakım, sağlık ve 
barınma gibi koruyucu ve destekleyici tedbir kararları verebilir (ÇKK Madde 5). Mahkeme tarafından verilen karar doğrultusunda sosyal çalışma görevlisi bu tedbirlerin ilgili kurum ve kuruluşlar tarafından uygulanıp uygulanmadığı konusunda denetimlerde bulunabilir ve çocuk hâkimini bu konuda bilgilendirir.

\section{Ekolojik Sistem Yaklaşımı}

Bronfenbrenner (1979) tarafından geliştirilen Ekolojik Sistem Yaklaşımında; bireyin sosyal çevresi, bir dizi iç içe geçmiş halkadan oluşmakta ve birey bu halkaların merkezinde yer almaktadır. Bireye görece daha uzak halkalar, kültürü ve toplumsal değerleri temsil ederken; daha yakın halkalar aile, okul gibi daha küçük ölçekli ortamları temsil etmektedir. Ekolojik sistem yaklaşımına göre birey ve çevresi arasında kurulan dengeyle bireyin sosyal çevresinden kaynaklı sorunları önlenebilir (Danış, 2006). Ancak bireyin yakın ilişki kurduğu kişilerle (mikrosistem) olan ilişkilerde bozulma olursa (örn; ebeveynleriyle sağlıklı ilişki kuramaması) çocuğun çevresindeki yaşantıları keşfetme süreci engellenebilir. Bu durum özellikle ergenlik döneminde, antisosyal davranışlar, düşük akademik başarı ve öz denetimi sağlamada problemlerin ortaya çımasına neden olabilir (Siyez, 2009).

Ekolojik Sistem Yaklaşımın Katmanları. Bronfenbrenner (1979) tarafından öne sürülen sosyo-kültürel katmanlar, bireyin yakın ilişki içerisinde olduğu aile ve yakın arkadaşlardan başlayarak bireyin doğrudan bir ilişkisinin olmadığı yasal düzenlemeler gibi sistemlere kadar uzanmaktadır. Organizma, Mikrosistem, Mesosistem, Eksosistem, Makrosistem ve Kronosistem olarak sıralanan bu sistemler arasındaki ilişkiler gelişim süreci içinde değişebilmektedir. Özellikle birey olmak üzere her bir sistem canlıdır ve değişkendir. Bireydeki bu değişim üst sistemleri etkilemekte birlikte birey ve üst sistemler arasında karşılıklı bir etkileşim söz konusudur (Bilge, Avcı, Dinçel, Alkış Demirel, Karatekin, Koç ve Demirtaş-Zorbaz, 2015).

Organizma. Bireye ait tüm özellikleri içerir. Ergenlerde suça sürüklenme riskini artıran antisosyal davranışlar, yüksek dürtüsellik düzeyi bu basamak içerisinde yer alabilir. 
Mikrosistem. Bireyin yakın ilişki içerisinde olduğu etkileşimleri ifade eder. Birçok ergen için bu arkadaş çevresi, aile ve okul ile ilişkiler olabilir. Ergenlerin suça sürüklenme davranışı ele alındığında mikrosistemde yer alan ilişkilerden ergen rol model alarak olumsuz etkileniyor olabilir. Polat’a (2004) göre, çocuğun içinde bulunduğu akran grubunun suçluluğa eğilimi çocuğun da bu davranışlara sürüklenmesine neden olabilmektedir. Ayrıca aile bireylerinin birbirlerine karşı olumsuz tutum ve davranışları çocuğun gelişimini olumsuz etkileyerek suça yönelmesine neden olabilmektedir (Akyüz, 2000).

Mesosistem. Bu katmanda mikrosistemdeki birimlerin birbirleriyle etkileşimi ve bireye etkisi ifade edilir (Berk, 2012). Örneğin okul-aile işbirliğinin çocuğun akademik başarısına etkisi ya da aile-akran ilişkilerinin çocuğun ebeveyn denetimine katkısı gibi. Suça sürüklenme ile ilgili yapılan araştırmalarda okul aile arasındaki işbirliğinin ve ebeveyn denetiminin koruyucu bir faktör olduğu belirtilmektedir (Siyez, 2009).

Eksosistem. Sosyal medya, kitle iletişim araçları, yasal mevzuat gibi bireyin gelişiminde dolaylı etkisi olan birimlerim oluşturduğu katmandır. Genel eğitim politikaları, medya ve kitle iletişim araçları bu birimlere örnek verilebilir (Gençtanırım, 2015).

Makrosistem. Yaklaşımın bu katmanında bireyin yaşadığı toplumun özellikleri yer alır. Kültürel değerler, ırksal ilişkiler, benimsenen din bunlara örnek verilebilir.

Kronosistem. Önceki tüm katmanları kaplayan bu dış katman yaşanan zaman dilimini ifade etmektedir. Örneğin, savaşlarda ve ekonomik kriz dönemlerinde suç davranışlarında artış olabilmektedir.

Ekolojik Sistem Yaklaşım ve Çocuk Adalet Sisteminde Kullanımı. Çocuk suçluluğuna bütüncül bir bakış ile ele alındığında kişisel özelliklerinin yanı sıra aile ve çevreye ilişkin faktörlerin önemli bir rol oynadığ $\mathrm{Bu}$ çerçevede bütüncül bir bakış açısı sunan ekolojik sistem yaklaşımın çocuk adalet sisteminde en yaygın kullanıldığı aşama sosyal inceleme süreci olmakla birlikte, bunun en somut belgesi Sosyal İnceleme Raporları (SİR)dır. SİR'ler sosyal çalışma görevlileri tarafından hazırlanan "çocukların suça sürüklenme 
nedenlerini ortaya koyarak gereksinim duydukları müdahaleyi öneren belgelerdir. SİR'de hareket noktası "suça sürüklenmiş çocuk"tur. Ancak çocuk suçluluğunun çok değişkenli doğası göze alındığında, SİR'de sadece "çocuk" değil, tıpkı ekolojik sistem yaklaşımın "çevresi içinde birey" kavramında olduğu gibi "çevresi içinde çocuk"tur.

Nadir (2011) tarafından suça sürüklenen çocuk ve ailesi ile ekolojik sistem yaklaşımı temelinde yapılan yaklaşık sekiz aylık süre ve 12 görüşmeden oluşan vak’a çalışması sonucunda; ekolojik sistem yaklaşımının suça yönelen çocuk ve sosyal çevresi ile yapılan uygulamalarda uzmana çok önemli bir teorik zemin sunduğu ve suça sürüklenen çocukta beklenen davranış değişiminin önemli anahtarlarından biri olduğu belirtilmiştir. Ekolojik sistem yaklaşımının adalet sisteminde kullanımının araştırıldığı bir başka çalışmada Braun (2012) hapishane mahkûmlarının topluma geçiş sürecinde aile içi şiddet girişim düzeylerini incelemiştir. Bu kapsamda bireysel, durumsal ve sosyal faktörler ele alınmıştır. Hapishaneden çıkarılan bireyin ailesi, arkadaşları mikrosistem ve buradaki ilişkilerinin birbiri ile etkileşimleri mezosistem olarak düşünülmektedir. Toplumun suçlulara ilişkin algısı veya kültürel inançlarının makrosistem olarak kişiler arası etkileşimleri üzerinde rol oynadığ belirlenmiştir.

Çocukların suça sürüklenmelerinin nedenleri çok boyutlu olmakla birlikte bireye özgüdür ve çok yönlü müdahaleleri gerektirmektedir. Toplumların geleceği olan çocukların suça sürüklenmesi sadece çocukları değil toplumun bütün bireylerini etkileyen bir sorundur. Bu nedenle suça sürüklenen çocuklarla yapılacak müdahalelerde çok yönlü yaklaşımlara ihtiyaç duyulmaktadır. Yapılan bu çalışmada ekolojik sistem yaklaşımının suça sürüklenen çocuklara yapılan müdahalelerde etkililiği bir olgu çerçevesinde tartışılmıştır.

\section{Yöntem}

$\mathrm{Bu}$ çalışmanın amacı, suça sürüklenen çocukların psikososyal değerlendirmesinde ekolojik sistem yaklaşımının kullanılmasını bir olgu çerçevesinde incelemektir. Olgu; 16 yaşında, Ankara Çocuk Mahkemesine Şubat 2015 ayında "taksirle bir kişinin yaralanmasına neden olma" suçundan 
hakkında ceza davası açılan ve çalışmaya katılmayı kabul eden M'dir. M’ye öncelikle çalışma hakkında bilgi verilmiş ve hazırlanan yarı yapılandırılmış görüşme formu çerçevesinde görüşmeler yapılmıştır. Bu süreçte her biri 45 dakika süren M ile iki, ebeveynleri ile bir oturum gerçekleştirilmiştir.

\section{Olgu; $M$,}

M, 16 yaşında, erkek, lise birinci sınıfta öğrenim görürken derslerinde yeterince başarılı olamaması ve kendi ifadesi ile "arkadaş ortamından dolayı okula devamsızlı̆̆ı" nedeniyle örgün öğrenimini sonlandırmış ve sonrasında açık liseye kaydını yaptırmıştır. Akademik not ortalaması 100 üzerinden 50'dir.

M, örgün öğrenimini bıraktıktan sonra bir yıl organize sanayi sitesinde bir otomobil tamircisinin yanında çalıştı̆̆ını, burada rot-balans işini öğrendiğini, daha önceden de sanayi ortamına aşina olduğunu çünkü dedesinin de sanayici olduğunu ve oto sanayisine çok gittiğini belirtmiştir. $M$, rot-balans işinden aylik ortalama 500 TL kazandiğın, askerlik görevini yapıp geldikten sonra maddi koşulları elverirse rot-balans işi yapan bir tamirhane işletmeyi düşündüğünü aktarmıştır.

M, daha önce hiç adliyeye gelmediğini, başka mahkemelerde de halen görülen bir davasının ve sabıka kaydının bulunmadığını, çocuk mahkemesine de "taksirle bir kişinin yaralanmasına neden olma" suçundan geldiğini ifade etmiştir. M, hakkında açılan ceza davasına konu olan olaya ilişkin olarak; araba kullanmayı çok sevdiğini, yaşının küçük olduğunu ve ehliyetsiz araç kullanmanın suç olduğunu bildiğini, olay günü babasının arabasın ailesinden habersiz aldığını, aracı kullanırken dikkatsiz davrandiğını ve kavşakta diğer araca çarptığını, çarpışmanın ardından korktuğunu ve olay yerinden kaçtığını, daha önce de ailesinden habersiz de birçok çok kez araç kullandığını belirtmiştir.

$M$, ailesi ile ilgili olarak, annesi ve babasının ilkokul mezunu olduğunu, babasının düzenli bir işinin bulunmadı̆̆ını, annesinin ise herhangi bir yerde çalışmadığııı, dokuz yaşında bir erkek ve 11 yaşında bir kız kardeşinin bulunduğunu, kendisinin ailenin en büyük çocuğu olduğunu ifade etmiştir. M, Ankara’nın Yenimahalle ilçesinde ailesi ile birlikte yaşadığını, evlerinin amcasına ait bir apartman dairesinden oluştuğunu, bu nedenle kira vermediklerini, 
evdeki eşya koşullarının ailesinin ihtiyaçlarını karşılamada yeterli düzeyde bulunduğunu, evde kendisine ait odasının bulunmadığını, erkek kardeşi ile aynı odayı paylaştığını, ailesinin ekonomik durumunu bilmediğini, sadece kendi çalıştığı maaşını bildiğini aktarmıştır.

$M$, arabayı ailesinden izinsiz ahp, ehliyetsiz araç kullanırken kaza yapmasının ardından ailesinin kendisine çok kızdı̆̆ını, babasının arabasının anahtarın artık kendisinden saklamaya başladiğını, ailesinde en yakın ilişkisi olan kişinin küçük erkek kardeşi olduğunu, ailesi ile sorunlarını paylaşmadığını, daha çok arkadaşlarına anlattığını belirtmiştir. $M$, okulda öğrenim görürken ailesinin ödevlerine ve derslerine yardımcı olmadiğını, zaman zaman ailesi tarafından anlaşılmadiğını hissettiğini, ancak yine de ailesinin kendisini sevdiğini düşündügünü ifade etmiştir.

M’nin ebeveynleri ile yapılan görüşmede; babası $M$ ile yeterince ilgilenemediğini, çoğunlukla iş aradığını ve kısa süreli işlerde çalıştığını, davaya konu olan olaydan sonra M'ye çok kızdiğını, okuyamaması nedeni ile M'yi oto sanayisinde işe yerleştirdiğini ancak yine de başarılı olamadiğın düşündüğ̈̈nü belirtmiştir. M’nin annesi ise M'nin içine kapanık bir çocuk olduğunu evde kendileri ile pek konuşmadı̆̆ını, genellikle arkadaşları ile gezdiğini, ne yaptı̆̆ını ise kendilerine pek anlatmadiğını aktarmıştır. Anne olaydan sonra M’ye karşı daha dikkatli davranmaya başladığını, onu dinlemeye çalışmışsa da pek başarılı olamadığını ifade etmiştir.

M, arkadaşlarını okuldan ziyade daha çok mahalleden edindiğini, birçok arkadaşının bulunduğunu, arkadaşları ile hemen her gün görïştüğünü, arkadaşlarının sürücü ehliyetinin bulunduğunu ancak sürücü ehliyeti olmayanların da araç kullandığını ve arkadaşları ile arabayla gezdiklerini aktarmıştır. M, Tofaş marka arabaları çok sevdiğini, ailesinin araba ile gezdiği arkadaşlarını tanımadığını ancak mahalleden diğer arkadaşlarını tanıdıklarını, arkadaşlarının eviniziyaret etmediklerini ancak kendisinin bazen arkadaşlarının evini ziyaret ettiğini, arkadaşları ile evde vakit geçirmediklerini belirtmiştir. $M$, arkadaşlarının birbirlerine lakap takmalarından ve küfürlü konuşmalarından rahatsız olduğunu, kendisine de lakap taktıklarını ve bundan hoşlanmadiğını ifade etmiştir. M, duygusal anlamda flört ilişkisinin bulunmadiğını, ancak kız 
arkadaşlarının bulunduğunu, daha önce de duygusal bir ilişkisinin olduğunu ancak, hemen terk edildiğinden duygusal ilişkilere sıcak bakmadiğını aktarmıştır.

M, lise öğrenimi sırasında öğretmenlerinin kendisini "arkadaşlarına çok kapılyyorsun" diyerek uyardıklarını ancak kendisinin bunu dinlemediğini, beden eğitimi ve resim dersi dışında tüm derslerde başarılı olamadığın belirtmiştir. $M$, okula sıklıkla devamsızlık yaptı̆̆ını ve devamsızlık yaptığı dönemlerde de rapor aldiğını, daha önce bir kez okuldaki bir tartışma nedeni ile okul rehberlik servisine yönlendirildiğini, bunun dışında psikolojik yardım almadığını, okulda uyuşturucu madde kullanan arkadaşlarının bulunduğunu, bundan rahatsız olduğunu ifade etmiştir.

Sinema, tiyatro gibi kültürel aktivitelere katılmadiğını ancak arabalarla ilgili filmleri sevdiğini, örneğin Hizh ve Öfkeli serisinin yeni filmi geldiğinde arkadaşları ile sinemaya gideceğini, spor ile ilgilenmediğini, sadece arkadaşları ile birlikte internet kafede futbolla ilgili playstation (oyun konsolu) oynadiğını, bir aralar pitbul köpeği beslediğini belirtmiştir.

Daha önce okul rehberlik servisi dışında herhangi bir psikolojik yardım almadığını belirten $M$, bugüne kadar onu derinden etkileyen travmatik bir olay yaşamadığını aktarmıştır. $M$, alkol ve uyuşturucu madde kullanmadığını ancak sigara kullandiğını belirtmiştir.

M, adliyede olmaktan dolayı kendisini kötü hissettiğini, pişman olduğunu, yaptığı davranışın suç olduğunu bildiğini ancak arkadaşları arasında hemen herkesin ehliyetsiz araç kullandığını, olay gününü geriye almak istediğini, büyümek istemediğini, sorumluluk almay sevmediğini hep küçük kalmak istediğini aktarmıştır.

$M$, oto sanayisindeki işini sevdiğini ve rot-balans işinde iyi olduğunu, burada araba kullanmasının desteklendiğini, kendi ifadesiyle "araba hastalı̆̆ının" bulunduğunu aktarmıştır. $M$ bu duruma yönelik olarak arabanın hayatındaki ilgi ihtiyacını karşıladığını, örneğin araba kullanırken insanların kendisine bakmasının hoşuna gittiğini, onların kendisine imrendiklerini düşündüğ̈̈nü ifade etmiştir.

Mile yapılan görüme sürecinde; M’nin biyo-psiko-sosyal olarak yaşına uygun 
gelişim düzeyinde bulunduğu, genel görünümü itibariyle de sağlıkl göründüğü, giyim-kuşamının temiz olduğu, kendisine yöneltilen soruları anlayabildiği ve bunlara uygun yanıtlar vermekte zorlanmadı̆̆l, konuşma tonunun ve hızının normal olduğu, göz teması kurabildiği, yaşantılarını paylaşma konusunda istekli ve iletişime açık olduğu, kendisini uygun ve sakin bir şekilde ifade edebildiği gözlenmiştir.

\section{Ekolojik Sistem Yaklaşım Temelinde Olgu Formülasyonu}

Ekolojik sistem yaklaşımı uygulayıcılara çok geniş bir bakış açısı sunar. Bu bakış açısı bireyi merkeze alarak onun çevresi içerisinde davranışlarını ele almaktadır. Jessor ve Jessor (1977) ergenlerde problem davranışları ele alırken; risk (tetikleyici) faktörleri riskli davranışlarla ilgilenme olasılığını arttıran faktörler olarak tanımlanırken; koruyucu (kontrol edici) faktörler riskli davranışlarla ilgilenme olasılığını azaltan faktörler olarak tanımlanmaktadır. Aşağıda Jessor ve Jessor (1977) tarafından geliştirilen Problem Davranış Teorisi doğrultusunda M’nin ekolojik sistem yaklaşımı katmanlarına göre koruyucu ve risk faktörlerine yer verilmiştir. 
Tablo 1. M’nin riskli ve koruyucu davranış örüntülerinin ekolojik sistem yaklaşımı katmanlarına göre dağılımı

\begin{tabular}{|c|c|c|}
\hline $\begin{array}{l}\text { Ekolojik Sistem } \\
\text { Katmanları }\end{array}$ & Koruyucu Faktörler & Risk Faktörleri \\
\hline Organizma & $\begin{array}{l}\text {-Yaşına uygun gelişim düzeyinde } \\
\text { bulunması ve belirgin bir } \\
\text { psikopatoloji gözlenmemesi } \\
\text {-Okul terki sonrası açı öğretim } \\
\text { lisesine kayıt yaptırması } \\
\text {-Sabit gelirinin bulunması } \\
\text {-Sabıka kaydının bulunmaması } \\
\text {-Gelecek beklentisinin bulunması }\end{array}$ & $\begin{array}{l}\text {-Kendini kontrol düzeyinin düşük } \\
\text { olması } \\
\text { - Sigara kullanımı } \\
\text {-Akademik başarısının düşük olması } \\
\text { - Okul terki } \\
\text { - Sanayi ortamında çalışması } \\
\text {-Araba tutkusunun ilgi ihtiyacını } \\
\text { karşıladığını düşünmesi } \\
\text {-Sorumluluk almak istememesi }\end{array}$ \\
\hline Mikrosistem & $\begin{array}{l}\text {-Ailesinin kendisini -yine de- } \\
\text { sevdiğini hissetmesi } \\
\text {-Ailede kendisini küçük kardeşine } \\
\text { yakın hissetmesi } \\
\text {-Öğretmenlerinin M'yi arkadaş } \\
\text { çevresi konusunda uyarıda } \\
\text { bulunması } \\
\text {-İki kardeşinin bulunması } \\
\text {-Davaya konu olan olaydan sonra } \\
\text { annenin M’ye yakınlık kurmak için } \\
\text { çabalaması }\end{array}$ & $\begin{array}{l}\text {-Düşük sosyoekonomik düzey } \\
\text {-Ebeveynlerin düşük eğitim düzeyi } \\
\text {-Yetersiz aile içi iletişim } \\
\text {-Yetersiz ebeveyn kontrolü } \\
\text {-M’nin ailesi tarafından } \\
\text { anlaşılmadığını hissetmesi } \\
\text {-Aile bireyleri arasında sınırlı paylaşım } \\
\text { bulunması } \\
\text {-Riskli arkadaş çevresi } \\
\text {-Arkadaş çevresinin kendisine lakap } \\
\text { takması } \\
\text {-Romantik ilişkide hemen terk } \\
\text { edildiğinden bu ilişkilere sıcak } \\
\text { bakmaması }\end{array}$ \\
\hline$\stackrel{\text { Mesosistem }}{\downarrow}$ & $\begin{array}{l}\text {-Ailesinin M'nin mahalleden } \\
\text { arkadaşlarını tanıması }\end{array}$ & $\begin{array}{l}\text {-Aile ve okul yönetimi arasında } \\
\text { etkileşimin sınırlı olması } \\
\text {-Ailenin M'nin öğrenimine duyarsız } \\
\text { olması } \\
\text {-Ailenin M’nin araba ile gezdiği } \\
\text { arkadaşlarını tanımaması }\end{array}$ \\
\hline$\stackrel{\text { Eksosistem }}{\downarrow}$ & Veri yok & $\begin{array}{l}\text {-M’nin Hızlı ve Öfkeli gibi araba } \\
\text { konulu filmlere daha çok ilgi } \\
\text { göstermesi ve bu gibi filmlerde hızlı } \\
\text { araç kullanımının özendirilmesi }\end{array}$ \\
\hline Makrosistem & Veri yok & $\begin{array}{l}\text {-M’nin çalıştığı sanayi ortamında } \\
\text { araba tutkusunun pekiştirilmesi } \\
\text {-Yaşadığı sosyal çevrede uyuşturucu } \\
\text { kullanılıyor olması } \\
\text {-Arkadaş grubunda ehliyetsiz araç } \\
\text { kullanımının normal kabul edilmesi }\end{array}$ \\
\hline
\end{tabular}


Ekolojik sistem yaklaşımın temelini oluşturan ve bireysel özellikleri ifade eden organizma katmanında M'nin koruyucu faktörlerine Tablo l'de bakıldığında; yaşına uygun gelişim düzeyinde bulunduğu ve belirgin bir psikopatoloji gözlenmediği, ayrıca lise birinci sınıfta örgün öğrenimi sonlandırması sonrası açık öğretime kayıt yaptırdığı belirlenmiştir. Ayrıca M'nin sabıka kaydının bulunmadığı, oto sanayi sitesinde rot-balans işinde çalışarak sabit gelirinin bulunduğu ve geleceğe yönelik olarak askerlik görevini bitirmesinin ardından rot-balans işinde ilerlemek amacıyla bir tamirhane açmayı planladığı belirlenmiştir. Organizma katmanında risk faktörlerin özelliklerine bakıldığında ise; ehliyetsiz araç kullanmanın suç olduğunu bildiği halde daha önce birçok kez ailesinden habersiz araç kullandiğı ve bu yönüyle kendini kontrol düzeyinin düşük olduğu ayrıca sigara kullandığ1 belirlenmiştir. Okulda öğrenim görürken akademik başarısının düşük olması nedeni ile örgün öğrenimini sonlandırdığı, bunun sonucunda babasının da etkisi ile sanayi ortamında çalışmaya başladığı saptanmıştır. M’nin araba tutkusunun ilgi ihtiyacını karşıladığını düşünmesi anlamlı bir faktör olarak düşünülmüş ayrıca sorumluluk almak istememesi ve hep çocuk kalmak istemesi de dikkat çekici bulunmuştur.

Bireyin yakın çevresinde bulunan etkileşim ve aktiviteleri içeren mikrosistem katmanında koruyucu faktörlere Tablo 1'de bakıldığında; M'nin ailesinin kendisini -yine de- sevdiğini hissetmesi ve ailede kendisini küçük kardeşine yakın hissetmesi olumlu bir faktör olmakla birlikte öğretmenlerinin M'yi arkadaş çevresi konusunda uyarması, iki kardeşinin bulunması ve davaya konu olan olaydan sonra annenin M’ye yakınlık kurmak için çabalaması korucuyu faktörler olarak değerlendirilmiştir. Risk faktörlerine bakıldığında ise; ailenin sosyoekonomik düzeyinin ve ebeveynlerinin eğitim düzeyinin düşük olması ile aile içi iletişimin ve ebeveyn kontrolünün yetersiz olması önemli risk faktörü olarak görülmüştür. Ayrıca M’nin ailesi tarafından anlaşılmadığını hissetmesi ve aile bireyleri arasında sınırlı paylaşım bulunması da diğer önemli risk faktörleri olarak belirlenmiştir. M’nin riskli arkadaş çevresine sahip olması ile arkadaş çevresinin kendisine lakap takması ve 
romantik ilişkide hemen terk edildiğinden bu ilişkilere sıcak bakmaması da risk faktörü olarak değerlendirilmektedir.

Mikrosistemde yer alan birimlerin birbirleri ile olan etkileşimlerini ifade eden mesosistem katmanında M'nin koruyucu faktörlerine Tablo 1'de bakıldığında; sadece M’nin ebeveynlerinin M’nin mahalleden arkadaşlarını tanıması olarak belirlenmiştir. Riskli faktörlere bakıldığında ise; M’nin ebeveynleri ile ve okul yönetimi arasında etkileşimin sınırlı olması ve ebeveynlerin M’nin öğrenimine duyarsız kalması risk faktörü olmakla birlikte ebeveynlerin M’nin araba ile gezdiği arkadaşlarını tanımaması da bir diğer önemli risk faktörü olarak değerlendirilmiştir.

Bireyin gelişiminde dolaylı etkisi olan birimlerden oluşan sistemin oluşturduğu eksosistem katmanına Tablo 1'den bakıldığında koruyucu faktör olarak veri elde edilememiştir. Risk faktörü olarak ise; M’nin Hızlı ve Öfkeli gibi araba tutkusunu ele alan filmlere daha çok ilgi göstermesi ve bu gibi filmlerde hızlı araç kullanımının özendirilmesi risk faktörü olarak değerlendirilmiştir.

İçinde yaşanılan kültürel yapının ele alındığı makrosistem katmanına Tablo 1'de bakıldığında korucu faktör olarak veri elde edilememiştir. Risk faktörü olarak ise; M’nin çalıştı̆̆1 oto sanayi ortamında araba tutkusunun pekiştirilmesi ve arkadaş grubunda ehliyetsiz araç kullanımının normal kabul edilmesi ile yaşadığı sosyal çevrede uyuşturucu kullanılıyor olması önemli risk faktörleri olarak belirlenmiştir.

M'nin organizma aşamasından makrosisteme kadar olan sistem katmanlarında suça sürüklenmesini azaltan koruyucu faktörler olmasının yanında bunlardan daha etkili biçimde suça sürüklenmeyi arttıran çok sayıda risk faktörlerinin olduğu görülmektedir. Bu faktörlerin hepsinin bir arada alınması ve riskli davranışların değerlendirilmesinde M’nin çevresi içerisinde değerlendirilmesi M’ye yönelik hazırlanacak olan önleyici ve müdahale edici çalışmalara yol gösterici olacaktır. 
Ekolojik sistem yaklaşımı bireyin davranışını ele alırken birey ve çevresi arasındaki etkileşimin üç boyutunu birlikte değerlendirir. Bu boyutlar; normal gelişimsel özellikler, genel yaşam olayları ve bireysel farklılıkların etkileridir (Butler, 1996). Normal gelişimsel özellikler bireyin yaşam süreci içerisinde doğal olarak meydana gelen; biyolojik, psikolojik, duygusal ve entelektüel süreçleri içerir (Ashman ve Zastrow, 1990). Genel yaşam olayları ise, bireyin karşılanamayan ihtiyaçlarının yaşam döngüsünde meydana gelen değişimlerin (küçük, orta, büyük) şiddetidir (Danış, 2006). Birey ait olduğu grup yapısının toplum içinde yaşayan diğer gruplar ile arasındaki farklardan dolayı çok çabuk ayırt edilebilir. Birey kişisel farklılıklarının etkilerine de yakından bağlıdır (Ashman ve Zastrow, 1990). Bu kapsamda M'nin Tablo 1'de ele alınan risk faktörleri; ekolojik sistem yaklaşımının bireyin davranışını değerlendirirken birey ve çevresi arasında etkileşimin üç boyutu (normal gelişimsel özellikler, genel yaşam olayları ve bireysel farklılıkların etkileri) çerçevesinde Danış (2006) tarafından öne sürülen davranış dinamiklerini değerlendirme modelinden faydalanılarak Şekil 1'de sunulmuştur. 


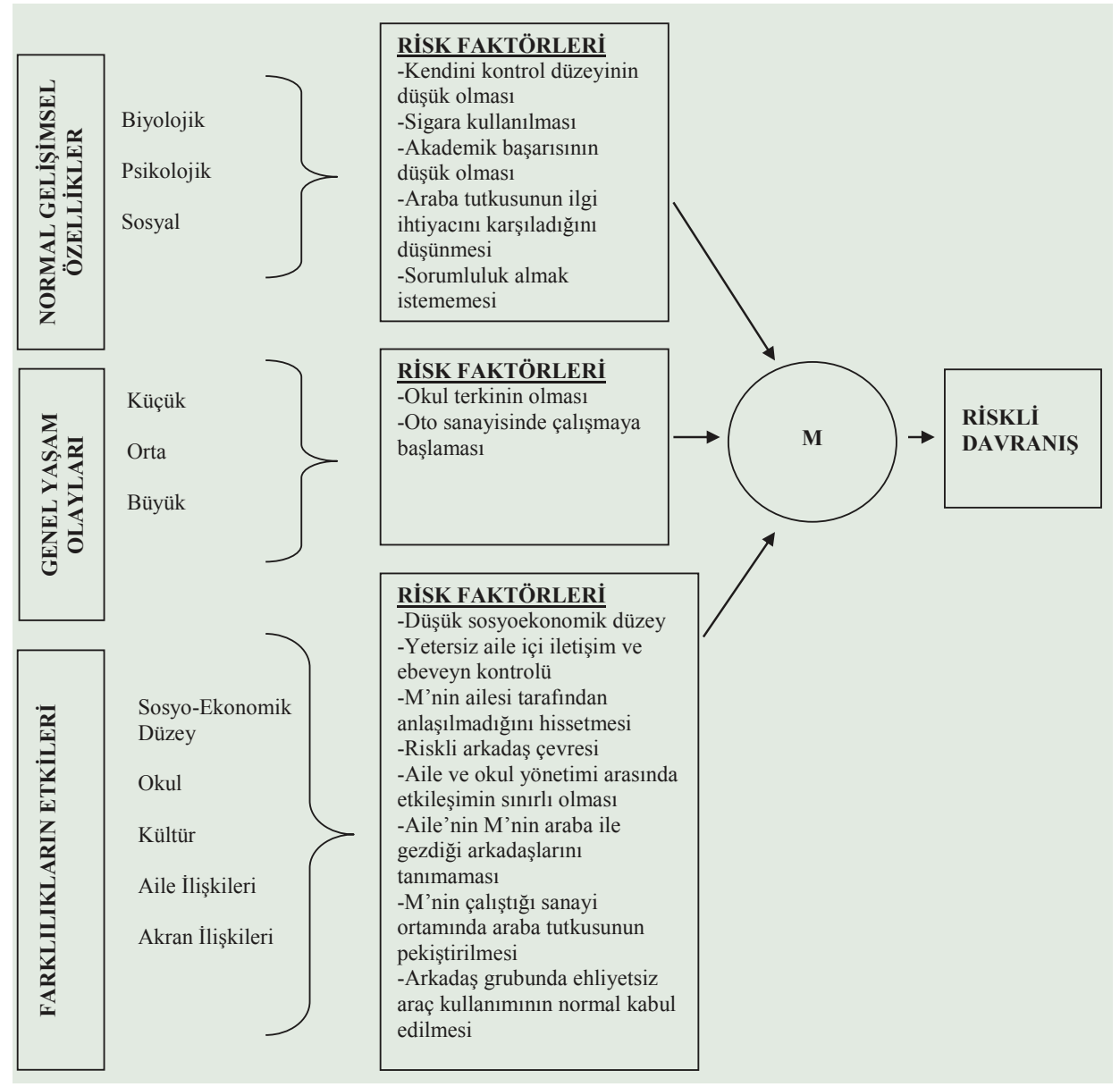

Şekil 1. M’nin riskli davranış dinamiklerinin değerlendirilmesi

Ekolojik sistem yaklaşımının davranış dinamiklerini değerlendirilmesinde kullanılan ilk boyut olan normal gelişimsel özelliklere Şekil 1'de bakıldığında; M’nin, kendini kontrol düzeyinin düşük olması, sigara kullanımı, akademik başarısının düşük olması, araba tutkusunun ilgi ihtiyacını karşıladığını düşünmesi, sorumluluk almak istememesi faktörleri gelişimsel olarak riskli davranışa etki eden faktörler olarak değerlendirilmiştir.

Genel yaşam olayları boyutuna Şekil l'de bakıldığında ise; M’nin lise birinci sınıfta örgün eğitimini sonlandırması ve bunun sonucunda oto sanayi 
sitesinde çalışmaya başlaması riskli davranışa etki eden önemli yaşam olayları olarak görülmektedir.

Farklılıkların etkileri boyutuna Şekil l'de bakıldığında ise; M’nin ilesinin düşük sosyoekonomik düzeyde bulunması, yetersiz aile içi iletişim ve ebeveyn kontrolü, M’nin ailesi tarafından anlaşılmadığını hissetmesi, riskli arkadaş çevresi, aile ve okul yönetimi arasında etkileşimin sınırlı olması, ailenin M’nin araba ile gezdiği arkadaşlarını tanımaması, M’nin çalıştığı sanayi ortamında araba tutkusunun pekiştirilmesi ve arkadaş grubunda ehliyetsiz araç kullanımının normal kabul edilmesi riskli davranışa etki eden faktörler olarak değerlendirilmiştir.

Sonuç olarak; yukarıda açılanan normal gelişimsel özellikler, genel yaşam olayları ve bireysel farklılıkların etkileri boyutlarına ele alınan risk faktörleri ele alındığında M’nin yargılama konusu olan "taksirle bir kişinin yaralanmasına neden olma" suçuna önemli düzeyde etki eden faktörler olduğu değerlendirilmiştir. 


\section{Sonuç ve Müdahale}

M’nin psikososyal durumu M ve ebeveynleri ile yapılan görüşmeler, dava dosyası içeriği ve ekolojik sistem yaklaşımı doğrultusunda değerlendirildiğinde; M'nin ailesi ve sosyal çevresi açısından suça yönelme konusunda risk altında olduğu, benzer davranışların tekrarlanmaması açısından hem M'ye hem de ebeveynlerine yönelik olarak koruyucu, önleyici ve müdahale edici çalışmalara ihtiyaç duyulduğu değerlendirilmiştir. Bu kapsamda M’nin ebeveynlerine; aile içi iletişim, ebeveynlik becerileri ve ebeveyn kontrolü ve ergenlik döneminde yaşanılan sosyal sorunlar gibi konularda rehberlik hizmeti sunulması düşünülmüştür. M’ye yönelik olarak sağlıklı bir ergenlik süreci geçirebilmesi amacıyla çocuğun yüksek yararı ilkesi de gözetilerek; yaşadığı sosyal ve psikolojik problemlere uygun çözüm bulması, karar verme becerilerinin geliştirilmesi, arkadaş seçimleri ve serbest zamanlarını değerlendirme konularında psikolojik danışmanlık hizmeti alması değerlendirilmiştir. Tüm bu nedenlerle hem $M$ hem de ailesi hakkında 5395 Sayılı Çocuk Koruma Kanununun 5/1-a maddesi uyarınca hakkında Danışmanlık Tedbiri kararı verilmesi kanaatine varılmıştır. $\mathrm{Bu}$ çerçevede $\mathrm{M}$ hakkında sosyal inceleme raporu (SİR) hazırlanmış ve mahkemeye sunulmuştur. M hakkında hazırlanan rapordaki değerlendirmeler çocuk mahkemesince de uygun görülmüş, $M$ ve ailesi hakkında Danışmanlık Tedbiri kararı verilmiştir. Bu tedbirin Aile, Çalışma ve Sosyal Hizmetler İl Müdürlüğü tarafından yerine getirilmesi kararlaştırılmıştır.

\section{İzleme}

İzleme çalışmaları, sağlanan gelişmenin sürdürülebilmesine ya da durumun tekrar gözden geçirilmesini sağlar. Çocuk mahkemesinde çalışan sosyal çalışma görevlilerinin izleme çalışmaları, hakkında tedbir kararı verilen çocuk hakkında uygulayıcılar tarafından yapılan müdahalelerin izlenmesi veya denetlenmesi sürecidir. $\mathrm{Bu}$ çerçevede tedbir kararı verilen çocuklara ilişkin uygulayıcılar tarafından yapılan müdahalelere ilişkin raporlar üçer aylık dönemlerle çocuk mahkemesine gönderilir (ÇKK Madde 8/2). M hakkında yapılan müdahalelere ilişkin Aile, Çalışma ve Sosyal Hizmetler İl Müdürlügü̈nden üçer aylık dönemlerle iki kez rapor geldiği görülmüştür. Bu 
raporlarda M’nin Danışmanlık Tedbiri müdahalesine olumlu yanıt verdiği, açık öğretim lisesine devam ettiği, arkadaş çevresinin değiştiği ve arkadaşlık ilişkilerinin geliştiği, ailesinin denetim ve kontrollerini arttırdığı, aile bağlarının güçlendiği bilgilerine yer verilerek Danışmanlık Tedbiri kararının kaldırılması talep edilmiştir. Bu talep çocuk mahkemesince uygun bulunarak M hakkında verilen Danışmanlık Tedbiri kararı sonlandırılmıştır.

\section{Değerlendirme ve Sonuç}

Ekolojik sistem yaklaşımı bağlamında ergenlerde suç davranışını tek bir faktörle açıklamak mümkün değildir. Birçok faktör bir arada ergenlerin suça yönelme davranışını arttırmaktadır. Çalışmada Mile yapılan görüşme süreci ve M hakkında bilgi verilmiş ve bu olgunun psikososyal durumu ekolojik sistem yaklaşımı katmanlarına göre koruyucu ve risk faktörleri olarak açıklanmıştır. Katmanlarda yer alan risk faktörleri değerlendirilirken Danış (2006) tarafından öne sürülen davranış dinamiklerini değerlendirme modelinden faydalanılmıştır. Çalışma sonucunda ekolojik sistem yaklaşımının suça sürüklenen çocuklara yapılan müdahalelerde etkili biçimde kullanılabileceği düşünülmektedir. 


\section{Kaynakça:}

Akyüz, E. (2000). Çocuğun haklarının ve güvenliğinin korunması. İnsan Hakları Eğitimi Dizisi. Ankara: Milli Eğitim Basımevi.

Ashman, K. K. \& Zastrow, C. (1990). Understanding human behavior and the social environment, Chicago: Nelson Hall Publishers.

Bilge, F., Avcı D., Dinçel, E. F., Alkış Demirel, E., Karatekin, H., Koç, Ö. \& DemirtaşZorbaz, S. (2015). The use of systems approach in pscyhological counseling and guidance. (Ed: Ş.Ş. Erçetin \& S. Banerjee). Chaos, Complexitiy and Lidership 2013. Springer İnternational Publishing: Switzerland.

Braun, M. J. F. (2012). Intimate partner violance during the transition from prison to the community: an ecological analysis. Doktora tezi, Portland State University.

Bronfenbrenner, U. (1979). The ecology of human development: Experiments by nature and design. Cambridge, MA: Harvard University Press.

Butler, S. (1996). Substance misuse and the social work ethos. Journal of Substance Misuse1, $62,(2), 46-53$.

Çocuk Koruma Kanunu (ÇKK). (2005). http://www.mevzuat.gov.tr/ MevzuatMetin/1.5.5395.pdf adresinden 16.08.2015 tarihinde erişildi.

Danış, M. Z. (2006). Davranış bilimlerinde ekolojik sistem yaklaşımı. Aile ve Toplum Dergisi, 8 (3), 45-53.

Gençtanırım, D. (2015). Ergen intiharlarının önlenmesi: Ekolojik bakış açısı. Ahi Evran Üniversitesi Kırşehir Eğitim Fakültesi Dergisi, 16, (1), 151-164.

Gökler, I. (2008) Sistem yaklaşımı ve sosyal-ekolojik sistem yaklaşım çerçevesinde oluşturulan kavramsal model temelinde kronik hastalı olan çocuklar ve ailelerinde psikolojik uyumun yordanması, Doktora Tezi, Ankara Üniversitesi Sosyal Bilimler Enstitüsü, Ankara.

Gülşen İçli, T. (2009). Çocuk suç ve sokak: Sokakta yaşayan suç işleyen ve suça maruz kalan çocuklar. Başbakanlık Aile ve Sosyal Araştırmalar Genel Müdürlügü Yayınları: Ankara. 
Haştemoğlu, G. (2012). Her şey çocuklar için ya adalet. Türkiye Çocuk Adalet Sistemine Sivil Toplum Gözüyle Bakış Projesi Kitabı: Ankara.

Jessor, R., \& Jessor, S. L. (1977). Problem behavior and psychosocial development: A longitudinal study of youth.

Nadir, U. (2011). Suça yönelen çocuk ve ailesi ile çalışma: Ekolojik sistem perspektifi çerçevesinde örnek bir vaka sunumu, Toplum ve Sosyal Hizmet, 22, (1),165-174.

Siyez, D. M. (2009). Ergenlerde problem davranışlar. Ankara: Pegem Akademi Yayıncılık.

Güler, G., Sungur, M. A., \& Kütük, M. Ö. (2018). suça sürüklenen çocukların klinik ve sosyodemografik özelliklerinin değerlendirilmesi. The Bulletin of Legal Medicine, 23(1), 39-46.

Polat, O. (2004). Kriminoloji ve kriminalistik üzerine notlar. Ankara: Seçkin Yayıncılık.

Siyez, D. M. (2009). Ergenlerde problem davranışlar. Ankara: Pegem Akademi.

Türkiye İstatistik Kurumu (2018). Güvenlik birimine suça sürüklenme ile gelen veya getirilen çocuk sayısı. http://www.tuik.gov.tr/UstMenu.do?metod=temelist adresinden 27.12.2018 tarihinde erişildi.

Wiium, N. \& Wold, B. (2009). An ecological system approach to adolescent smoking behavior. Journal of Youth Adolescence, 38, 1351-1363. 